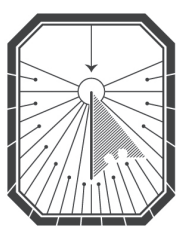

KYIV-MOHYLA

LAW \& POLITICS JOURNAL

KYIV-MOHYLA SCHOLARLY PEER-REVIEWED JOURNALS

Exploring Shades of Corruption Tolerance: Tentative Lessons from Iceland and Sweden

Author(s): Gissur Ólafur Erlingsson, Gunnar Helgi Kristinsson

Source: Kyiv-Mohyla Law and Politics Journal 5 (2019): 141-164

Published by: National University of Kyiv-Mohyla Academy

http://kmlpj.ukma.edu.ua/ 


\title{
Exploring Shades of Corruption Tolerance: Tentative Lessons from Iceland and Sweden
}

\author{
Gissur Ólafur Erlingsson \\ Centre for Local Government Studies \\ Linköping University, Sweden \\ Gunnar Helgi Kristinsson \\ Department of Political Science \\ University of Iceland, Iceland
}

\begin{abstract}
The aim of this paper is to explore the effects of corruption tolerance on corruption levels. Strong claims are made in the literature to the effect that tolerance of corruption is universally low. We show, however, that there are non-trivial variations in tolerance of corruption, and that these are significantly related to commonly used indices of corruption. This suggests that understanding which factors shape corruption tolerance is important. Here, our concern is with the effects of elite structures on corruption. We first ask if closeness to power affects corruption tolerance and if the general population is less tolerant than elite groups. We then ask if different elite groupse. g., politicians and civil servants respectively - are likely to form different standards regarding corruption. To hold certain external variables constant, the paper focuses on two relatively homogeneous, low-corruption countries: Sweden and Iceland. Our findings suggest that whereas little supports the closeness to power hypothesisthe general population is not less tolerant of corruption than elites - there may be important differences in how different elite groups within these countries view corrupt activities. This has implications for how corruption can be contained.
\end{abstract}

Key Words: corruption, tolerance of corruption, norms, social trust, quality of government, public administration, bureaucratic ethics.

\section{(7)}

\section{Introduction}

The growing literature on corruption has established, beyond reasonable doubt that levels of corruption vary strongly between states, regions and local governments around the world. Irrespective of corruption definitions or which measurement techniques are used, some groups of states are, by all accounts, less corrupt and others are more so. Despite the methodological challenges, perhaps the major challenge facing corruption research is how to disentangle causality: why is corruption greater in some political 
units than in others? Suggested candidates for causes of corruption are many and varied. Here, we have no ambition to review extensively this literature. Instead, we aim to explore the role of attitudes as contributing factors to variations in corruption. More precisely, we ask: are corruption levels influenced by tolerance of corruption within societies?

To address this question, we will demonstrate that claims in the literature diverge sharply regarding how the question is answered. Whereas some maintain that attitudes are largely irrelevant to actual corruption levels, others maintain they may be a contributing factor. The issue's significance in the fight against corruption is beyond doubt. If corruption is not affected by attitudes, no amount of disseminating information, forming guidelines, establishing ethics committees or strengthening professional standards will be successful in fighting it. By contrast, if attitudes indeed play a role, we need to know why they vary and how these variations can be used in creating safeguards against corruption.

The relevance of attitudes such as corruption tolerance depends to a certain extent on elite structures, i. e., the distribution of power within a society. The public, elites, and even different elite groups (e. g., politicians versus civil servants) may hold different attitudes on corruption. If they do, elite structures could be crucial to understanding the frequency of corruption. According to the populist vision of society, the most important political divisions lie between 'corrupt elites' and the 'pure people.' 1 This suggests that elites are more corrupt than the people and, consequently, presumably more tolerant of corruption. A different variant of the elite structure approach, however, is concerned less with the contrast between the people and elites than the interrelationship between different elites and how they may create safeguards against abuses of power when that interrelationship is properly balanced. If it can be established that politicians and civil servants have different attitudes to corruption or have varying sensitivity to the different forms it may take, this should tell us something about how the balance between politicians and bureaucrats may affect corruption.

In order to sharpen our theoretical expectations, we begin with a short exposition of major claims concerning the importance of corruption tolerance for actual corruption levels. This is followed by a discussion of the role of elite structures and the development of the hypotheses we will test. We then present our data and major findings. Given the relative scarcity of research in the area of corruption tolerance, we emphasize the explorative and somewhat tenuous nature of our approach to the research question and our somewhat tentative conclusions. However, our aim is to show that corruption tolerance seems to be related to actual corruption levels, that the public is not less tolerant of corruption than elites, but that different elites vary in their tolerance of corruption. 


\section{Does Corruption Tolerance Make a Difference?}

Influential authors working in the rational choice framework make claims that suggest tolerance of corruption is largely irrelevant to corruption and/or that corruption is universally disliked or shunned. For instance, some "institutional rational choice" perspectives seek to explain corruption by the opportunities presented to persons. According to this perspective, being involved in corrupt activities has nothing to do with "tolerance" per se. Instead, individuals act corruptly as the result of cost-benefit calculations. They weigh potential gains against the perceived costs and risks of getting caught. Norms/values are thus assumed to be largely irrelevant. This is the broad gist of the arguments raised by scholars such as Gary Becker; i. e., that corruption will result from cost-benefit calculations where the structure of temptation (potential benefits weighted against risks) favors it. ${ }^{2}$

Another attempt at grappling the relationship between corruption tolerance and corruption - still within a broadly rational choice framework - is to view corruption or its absence as emanating from the failure to overcome collective action problems. ${ }^{3}$ If corruption is caused by a 'pure' collective action problem, those who wish to eliminate corruption will not act this way because they believe that changing their own behavior will not sufficiently benefit them to justify action. Hence, they are likely either take advantage of the opportunity to act corruptly or at least tolerate ongoing corruption, despite their nobler instincts. As is often said about the NYC police officer Frank Serpico, it is hard to be "the only honest cop in town." Hence, even the least corruption-tolerant individuals will ultimately tolerate or comply with corruption norms, miring societies in what Bo Rothstein has labeled "a social trap." 4 The collective action approach is consistent with the contention that corruption indeed can persist in the absence of corruption tolerance. In Making Sense of Corruption, Bo Rothstein and Ayisha Varraich discuss an intimately related topic, and reject the idea that corruption tolerance significantly contributes to corruption:

“...corruption is seen by many as a relativistic concept where culture, history and language play a role in how the term is understood.

2 Gary S. Becker, “Crime and Punishment: An Economic Approach," The Journal of Political Economy 76, no. 2 (1968): 169-217. Similar lines of reasoning are also found in Michael Collier, "Explaining Corruption: An Institutional Choice Approach," Crime, Law and Social Change 38, no. 1 (2002): 1-32, as well as Staffan Anderson and Gissur Ó Erlingsson, "New Public Management and Danger Zones for Corruption," in The Social Construction of Corruption in Europe, ed. Dirk Tänzler, et al (Farnham, Burlington: Ashgate Press, 2012), 33-58.

Bo Rothstein, “Anti-Corruption: the Indirect 'Big Bang' Approach," Review of International Political Economy 18, no. 2 (2011): 228-50; Anna Persson, Bo Rothstein and Jan Teorell, "Why Anticorruption Reforms Fail: Systemic Corruption as a Collective Action Problem," Governance 26, no. 3 (2013): 449-71.

4 Bo Rothstein, Social Traps and the Problem of Trust (Cambridge: Cambridge University Press, 2005). 
However, such an analysis ignores the fact that corruption appears to be something that all societies shun and that it is not confined to the Western states."

They then present evidence from the Afrobarometer to assert that, no matter what societies or culture one considers, people generally dislike corruption. An implication of the collective action approach, therefore, would be that we expect little or no variations in the tolerance of corruption, even if corruption behavior may vary. Corruption, then, is presumptively universally shunned. Thus, taking this seriously, a strong theoretical case exists for ignoring corruption tolerance as a factor that affects corruption.

However, a challenging, and somewhat controversial strand in the corruption literature concerns the role played by 'culture' or 'tradition' in either promoting or inhibiting corruption. A particularly provocative question is whether corruption reflects a cultural orientation, or in the spirit of de Maistre's dictum, that "every nation gets the government it deserves." Given that several studies have argued that corruption tolerance may affect the occurrence of corruption, ${ }^{6}$ unsurprisingly scholars such as Levi and Rothstein ${ }^{7}$ maintain that societies must ensure that future decision makers are ethically properly equipped. For that reason, Levi and Rothstein propose that institutions of higher education should adapt their training to instill ethical and critical thinking, as well as skills to deal with ethical dilemmas. Furthermore, several countries have introduced ethical codes or codes of conduct aimed at strengthening public sector ethics. ${ }^{8}$ Thus, obviously, both scholars and policymakers at least implicitly recognize the importance of low tolerance vis-á-vis corruption — at least among elites, i. e., politicians and civil servants within bureaucracies.

Bo Rothstein and Ayisha Varraich, Making Sense of Corruption (Cambridge: Cambridge University Press, 2017); Sören Holmberg, Bo Rothstein and Naghmeh Nasiritousi, "Quality of government: What you get," Annual Review of Political Science, 12 (2009): 135-61.

6 James Loyd Bierstaker, "Differences in Attitudes about Fraud and Corruption across Culture: Theory, Examples and Recommendations," Cross Cultural Management: An International Journal 16, no. 3 (2009): 224-50; Raymond Fisman and Edward Miguel, "Corruption, Norms and Legal Enforcement. Evidence from Diplomatic Parking Tickets," Journal of Political Economy 115, no. 6 (2007): 1020-48.

7 Lennart Levi and Bo Rothstein, "Educating Ethical Leaders and Critical Thinkers," University World News 12 (January 2018), http://www.universityworldnews.com/article. php?story=2018010915074826o. See also Katharina Becker, Christian Hause and Franz Kronthaler, "Fostering Management Education to Deter Corruption: What do Students Know about Corruption and Its Legal Consequences?" Crime, Law and Social Change, 6o, no. 2 (2013): $227-40$.

8 Stuart C. Gilman, Ethics Codes and Codes of Conduct as Tools for Promoting an Ethical and Professional Public Service: Comparative Successes and Lessons (Washington D. C: World Bank, 2005). 
So, although corruption may be generally disliked, there might be different shades to such dislikes. Those who expect ethical literacy to provide results in fighting corruption must essentially believe that lowering corruption tolerance will reduce corruption. We therefore indirectly challenge the "collective action" perspective that corruption tolerance universally shunned and follow the mainstream approach in our first hypothesis, $\mathrm{H} 1$ :

H1. Although corruption is widely disliked, tolerance of corruption is positively related to corruption levels.

The answer to this question begs another, no less important one: why should some people be more tolerant of corruption than others? According to the 'power corrupts' dictum, we might expect those closer to the centers of power to be more tolerant of corruption than others. Most forms of corruption are practiced in networks of people who benefit from it in one way or another. Those who benefit are insiders, while those who do not are outsiders. ${ }^{9}$ An important version of the rational perspective is principal-agent theory, which is based on the assumption that agents are generally self-interested and are likely to fall prey to temptations when facing a moral hazard. According to these assumptions, a person's proximity to power should contribute to a lenient attitude towards corruption. Presuming that elites hold the key to power in democratic government, we then should expect this group to be more tolerant of corruption than the public. The public suffers the cost of corruption without the elite's opportunities to take advantage of it. We have, according to this theoretical premise, something resembling the populist credo where "corrupt elites" are pitted against the "pure people," a version of the recurring "power corrupts"-hypothesis. ${ }^{10}$

\section{H2. Elite groups tend to be more tolerant of corruption than the general public.}

The "power corrupts"-hypothesis, however, may take a too simplistic view of a society's elite structure. Although it follows the classical elitists in depicting a dichotomous elite versus non-elite structure, more recent theorizing in many cases considers more complex terms. In a networked environment, the division between beneficiaries and losers may not necessarily follow the elite versus non-elite distinction. People's tolerance of corruption may reflect the incentive structure of the networks they belong to. Mass clientelism is an effective form of political organization that may involve large 
sections of both elites and the electorate competing for privileged access to selective goods and services. The experience of "buying votes" tends to reduce the disapproval of such practices even where they are recognized to be malevolent. ${ }^{11}$ Equally, however, the incentive structures may be tilted against acceding to corruption temptations. This might be the case in a strongly professionalized context, ${ }^{12}$ where, e. g., "frowning" and "fear of whistle-blowing" from low tolerance peers, incur higher costs than engaging in corruption. The proposed mechanism resembles what Mark Granovetter ${ }^{13}$ dubbed 'thresholds models of collective behavior': the more individuals engage in some behavior the more likely it is to lower the cost for others to participate in such action (or embrace such values).14 As Pranab Bardhan puts it: "corruption represents an example of what are called frequency-dependent equilibria, and our expected gain from corruption depends crucially on the number of other people we expect to be corrupt." 15 Of course and as suggested, these mechanisms are expected to work in the reverse direction as well.

The standards shaping political life in a democracy are likely to be different from the standards shaping the behavior of public administrators. ${ }^{16}$ After all, politicians are in the business of attracting votes and gaining seats and may be subject to a range of demands that public administrators often escape. Civil servants, by the same token, are in the business of shaping rules and implementing public policies in an impartial manner, irrespective of the current power holders or those who bear the effects of administrative decisions. In bureaucratic systems, they are likely to be evaluated according to their proficiency rather than their political acumen. Thus, there is an interesting strand in the public administration literature on "administrative ethics," where we find numerous examples of normative arguments from scholars who state that civil servants ought to have higher ethical standards than the general public and politicians, i. e., that there should be a distinct bureaucratic ethos or a public administration ethics. This literature suggests that we should expect lower tolerance for

11 Luigi Manzetti and Carole Wilson, "Why do Corrupt Governments Maintain Public Support," Comparative Political Studies 40, no. 8 (2007): 949-70; Ezeuiel Ocantos, Chad de Jontge and David Nickerson, "The Conditionality of Vote-Buying Norms: Experimental Evidence from Latin America," American Journal of Political Science 58, no. 1 (2014): 187-211.

12 Bernard Silberman, Cages of Reason. The Rise of the Rational State in France, Japan, the United States, and Great Britain. (Chicago: The University of Chicago Press, 1993).

13 Mark Granovetter, “Threshold Models of Collective Behaviour," The American Journal of Sociology 83, no. 6 (1978): 1420-43.

14 Timur Kuran, Private Truths, Public Lies. The Social Consequences of Preference Falsification, (Cambridge: Harvard University Press, 1997); Thomas Schelling, "Dynamic Models of Segregation," Journal of Mathematical Sociology 1 (1971): 143-86.

15 Pranab Bardhan, "Corruption and Development: A Review of the Issues," Journal of Economic Literature, 35, no. 3(1997): 1320-46.

16 Joel Aberbach, Robert Putnam and Bert Rockman, Bureaucrats and Politicians in Western Democracies, (Cambridge: Harvard University Press, 1981). 
corruption among civil servants than, for instance, citizens and politicians, depending on, e. g., self-selection and public service-motivation, education, socialization, and rolefulfillment.

As relevant and interesting as the administrative ethics literature is, empirical demonstrations of whether there in fact are differences in ethical orientations between civil servants on the one hand, and politicians and the ordinary public on the other, are uncommon. In other words, few studies have empirically put the administrative ethics-propositions to the test, whether bureaucrats in general do have different types of ethics than legislators and/or the general public or if they plainly hold the same norms and values as everybody else.

There are, however, exceptions. The evolving literature on public service motivation has found that individuals drawn to jobs in the public sector are more likely to have higher ethical standards than those who are not. ${ }^{17}$ And relevant to our endeavor here, Robert P. Goss's now more than 20-year-old study, in which he surveyed 778 civil servants in Colorado, USA, 46 elected members of the Senate, and 250 Colorado voters is highly suggestive. He also observed a separate public administration ethics. But, given the limited and context-bound data, he concluded that "further research would be helpful." ${ }^{18}$ Since we believe that questions relating to corruption tolerance have been somewhat neglected in the general literature on corruption and public administration, and because Goss's data is more than twenty years old, limited and contextually bound to Colorado, analyzing and comparing civil servant attitudes to corruption with that of the public and politicians' requires continuing his research.

That state capacity/strong bureaucracy and representative democracy are essential for achieving good governance is well-established. ${ }^{19}$ But how the worlds of democracy and bureaucracy interact may vary a great deal. And here, timing and sequencing matter. In some democratic systems, politicians were originally seen as mere guests in power, with little direct access to patronage or the implementation of policy. This, according to Martin Shefter, was the case where bureaucracy developed before the advent of democracy, a characteristic for many countries in Northern Europe and in some regions in North America. ${ }^{20}$ Where bureaucracy was underdeveloped at

17 Jan-Hinrik Meyer-Sahling, Kim Sass Mikkelsen and Christian Schuster, "The Causal Effect of Public Service Motivation on Ethical Behavior in the Public Sector: Evidence from a Large-

Scale Survey Experiment," Journal of Public Administration Research and Theory 29, no. 3 (2019): 445-59; Bradley Wright, Shahidul Hassan and Jongsoo Park, "Does a Public Service Ethic Encourage Ethical Behaviour? Public Service Motivation, Ethical Leadership and the Willingness to Report Ethical Problems," Public Administration 94, no. 3 (2016): 647-63.

18 Robert P. Goss, "A Distinct Public Administration Ethics," Journal of Public Administration Research and Theory 6, no. 4 (1996): 573-97.

19 Michelle D’Arcy, Marina Nistotskaya and Robert Ellis, “State-Building, Democracy and Taxation: Why Ireland Will Never Be Sweden," University of Tokyo Journal of Law and Politics 12 (2015): 110-23. 
the time of democratization, on the other hand, politicians were likely to gain a much stronger position within the administrative system, even to the point of hindering the development of strong administrative norms or the development of a sufficient degree of bureaucratic autonomy to counteract clientelism. As Samuel Huntington observed, democratizing before developing an effective bureaucracy may lead to differing outcomes compared to a situation where democracy was introduced after state-capacity had developed. ${ }^{21}$

\section{Bureaucrats and politicians have different standards of corruption tolerance.}

Нза: Bureaucrats are more sensitive to professional and procedural standards.

$\mathrm{H}_{3} \mathrm{~b}$ : Politicians are more dedicated to the idea of serving their political clientele.

\section{Data and Methods}

Our analysis proceeds in several steps. First, we attempt to establish whether enough meaningful variations in corruption tolerance exist to warrant further study. The availability of data restrains us here because few comparative surveys deal with corruption tolerance. We shall be using ESS data covering numerous European states in 2004, as well as the Eurobarometer from $2017 .{ }^{22}$ Second, we investigate whether tolerance of corruption is related to a commonly used proxy for corruption levels. Again, we use ESS and Eurobarometer data on corruption tolerance and, for corruption levels, Transparency International's Corruption Perception Index (CPI) data. Our aim is to establish, on one hand, if rejection of corruption is universal, and, on the other hand, if variations are systematically related to actual corruption levels variations $(\mathrm{H1})$.

Then we turn our attention to elite structures and tolerance of corruption. To do this, we need data that can be used for analyzing within-country variations as well as between countries. Such data is hard to locate and, to our knowledge, is not available in large scale multi-national projects. Hence, we use more limited comparisons based on data obtained in Iceland and Sweden. Although both countries belong to the category of "least corrupt" countries, they provide an interesting context for developing and testing theories of corruption. Thus, we have two relatively low-corrupt cases that share many of the cultural and constitutional features of highly developed democracies. Holding numerous external variables constant, comparisons between the two may contribute, therefore, to our understanding of how tolerance of corruption is shaped.

21 Samuel Huntington, Political Order in Changing Societies, (New Haven: Yale University Press, 1968). 
Table 1.

TYPES OF CORRUPTION: DESCRIPTION OF BEHAVIOR

\begin{tabular}{ll} 
BRIBES & $\begin{array}{l}\text { If you think of the Icelandic municipalities, how common or rare do you think it is that } \\
\text { politicians or public employees accept payments or special benefits for giving preferential } \\
\text { treatment to those offering them? }\end{array}$ \\
\hline EMBEZZLEMENT & $\begin{array}{l}\text { How often or rarely do you think politicians or public employees in the Icelandic municipalities } \\
\text { embezzle funds or draw income in excess of what they are entitled to? }\end{array}$ \\
\hline FRAUD & $\begin{array}{l}\text { How often or rarely do you think politicians or public employees in Icelandic municipalities } \\
\text { conceal important information or intentionally give misleading information to avoid criticism? }\end{array}$ \\
\hline EXTORTION & $\begin{array}{l}\text { How often or rarely do you think politicians or public employees in Icelandic municipalities } \\
\text { give in to treats of one kind or another? }\end{array}$ \\
\hline FAVORITISM & $\begin{array}{l}\text { How often or rarely do you think politicians or public employees in the Icelandic municipalities } \\
\text { discriminate among applicants for jobs on the grounds of political connections, cronyism or } \\
\text { nepotism? }\end{array}$ \\
\hline $\begin{array}{l}\text { PRIVATE } \\
\text { INTERESTS }\end{array}$ & $\begin{array}{l}\text { How often or rarely do you think politicians or public employees in Icelandic municipalities } \\
\text { cultivate relations to influential interest groups or businesses in the community and serve their } \\
\text { interests in local government? }\end{array}$
\end{tabular}

Note: Alternatives for answers on tolerance of these types of corruption were:

$1=$ intolerable, $2=$ rather undesirable, $3=$ can be all right, and $4=$ all right .

Comparing corruption tolerance among elites and non-elites, we use data from Icelandic municipalities. Aiming to establish (see below) that there are sufficiently important variations in corruption tolerance, we use data from municipal level corruption research which covers both the public and municipal elites (politicians and administrators). The Icelandic data was obtained in parallel surveys conducted by the Social Science Research Institute among the public, municipal employees and members of municipal councils. ${ }^{23}$

Here we probe Icelandic data for systematic differences in the attitudes of politicians, administrators and the public towards corruption. Since bribes may not be the most common form of corruption in countries with relatively little corruption, we ask for respondents' attitudes to a number of different types of activities relating to various kinds of abuses of power for private gain (or to favor those one has ties to), without mentioning the word corruption. ${ }^{24}$ Respondents were first asked how common

23 Sample among public was 1502 and net response rate 66 percent. Among municipal employees and representatives, the sample size was 302 and net response rate 70 percent.

24 The problem with using only attitudes or experiences of bribery to corruption-related phenomena is that bribes may not be the most relevant type of corruption in all settings. In the North European setting, for example, very few people claim to have any experience of having been asked to pay bribes. Other activities may be more relevant, what has been called 'gray' or 
they thought a number of different types of corruption are and after that whether or to what extent such behavior is justifiable. The activity in question is described in Table 1.

Finally, we analyze why and how inter-elite tolerance of corruption may vary between different elite groups within and between states. For this, we use data from both Iceland and Sweden obtained among municipal politicians and administrators. Our case selection is based on the argument that conditions for developing professional integrity, on the one hand, and the relative strength of political norms vs. administrative norms on the other, were crucial factors in shaping different levels of tolerance for different forms of corruption in the two cases.

The presence of corruption in Iceland has long been a contested issue. Early measurements by TI in the 2000 indicated that Iceland was among the least corrupt countries in the world, or even the least corrupt one (in 2005). This view was contested by some academics as well as large parts of the Icelandic population..$^{25}$ The TI's CPI is likely to be seriously biased for Iceland in at least two respects. First, the type of corruption that takes place is usually confined to grey or less serious types of corruption that the CPI does not cover adequately. Typical corruption in Iceland includes influence peddling, patronage appointments, pork-barrel, and the like. However, we rarely observe bribery or highly criminalized activity. Second, the CPI is strongly influenced by the perceptions of foreign businesspeople who may not be particularly knowledgeable about the corruption that occurs and may be highly susceptible to the influence of superficial or journalistic evaluations of corruption. Thus, after the economic crash of 2008, Iceland fell out of the CPI top-ten for the first time (e. g., 8 in 2009, 11 in 2010, 13 in 2011), despite no substantial evidence that corruption actually increased during this period. In fact, some evidence suggests that corruption may have decreased in many areas during the last three or four decades following a strong reform movement focused on strengthening the rule of law and improving administrative procedure. ${ }^{26}$ And, as been highlighted in previous studies, even before the financial crisis of 2008 , at a time when Iceland occupied top positions in international indices gauging good government and control of corruption, a substantial share of the citizens viewed corruption among politicians as quite common.

The roots of the Icelandic clientelism problem lie in the weaknesses of the administrative state during the crucial decades of state formation in the first decades

'sophisticated' corruption. In the Icelandic corruption study of 2015, we asked respondents for their attitudes to, and experiences of several different types of corruption.

See for instance: Gissur Ó. Erlingsson, Jonas Linde and Richard Öhrvall, "Distrust in Utopia? Public Perceptions of Corruption and Political Support in Iceland Before and After the Financial Crisis in 20o8," Government and Opposition 51, no. 4 (2016): 553-79; Gissur Ó. Erlingsson and Gunnar Helgi Kristinsson, "Measuring Corruption: Whose Perceptions Should We Rely On?" Icelandic Review of Politics \& Administration 12, no. 2 (2016): 215-35.

Gunnar H. Kristinsson, "Party patronage in Iceland: Rewards and control appointments," in Party patronage and party government in European democracies, eds. Peter Kopecky et al., (Oxford: Oxford University Press, 2012). 
of the 2oth century. The administration had been part of the Danish state and enjoyed very little legitimacy or political support among the political forces pressing for independence. Thus, with the emergence of Home Rule in 1904, an entirely new structure was established at the top levels of the administration that was subservient to the emerging political victors from the struggle for independence. The old administrative elite lost much of its former influence while the rising forces of class politics had little sympathy for the old privileged servants of the state. As soon as mass political parties began organizing during the inter-war period, they adopted clientelist methods of political organization, distributing political favors in exchange for political support. This benefited, among others, rural residents, who were overrepresented through the electoral system and the clientelist networks of the main contenders for power: the conservative Independence Party and the rural Progressive Party. The Social Democrats, which was much smaller than their Scandinavian counterparts, may have reaped some benefits from the system. But the communists/leftist-socialists can be considered political outsiders for the most part. Considerable support existed for the patronage system, especially among the sections of the population that benefited, which includes the rural, less professionalized sections of the population as well as political insiders. ${ }^{27}$

Growing opposition to clientelism since the 196os had roots in many different developments, including the liberalization of the economy, trends towards greater professionalization and a more independent media. Greater opposition to clientelism made questionable political practices riskier than before, and greater transparency increased the risk of being exposed. At the national level, a dedicated effort has been made since the 198 os to improve administrative procedure, leading, among other things, to greater separation than before between the worlds of politics and administration. At the local level, however, more of the old practices still exist. The local administration is extremely weak in many places and highly politicized, with politicians engaging directly in administrative activities that in the neighboring countries would be the exclusive domain of professional administrators.

If, as we have suggested, people adopt their evaluations of norms and behavior to some extent to roles and prevailing practices we should expect a) marked differences in the normative evaluations of politicians and administrators and b) political norms to prevail to a high degree in Icelandic local administration.

For all intents and purposes, Iceland and Sweden are often described as quite similar in the comparative politics literature, including, e. g., being classified as mature democracies and belonging to the 'Nordic welfare model'. And precisely like Iceland, Sweden has continuously been ranked high in TI's CPI; it has never been ranked lower than the sixth-least corrupt country in the world since the measure was launched in 1995. And it has always been at the top of the rankings when rule of law is being measured.

However, this has not always been the case. Swedish state-building and stateexpansion is typically traced back to the 16 th century, driven by warfare and military 
competition. ${ }^{28}$ Scholars analyzing Sweden's historical corruption records have pointed out that the system was clientelistic and rather corrupt until in the first half of the 19th century. However, Bo Rothstein tells a convincing story about how Sweden eradicated its corruption problem. ${ }^{29}$ By the end of the 19th century, long before the introduction of parliamentary democracy, corruption was basically eradicated. According to Rothstein, the problem was largely eradicated through a series of non-incremental, quite dramatic, "big bang" reforms. In a short time, these reforms changed a somewhat flawed, corrupt and unprofessional bureaucracy into a Weberian-type bureaucracy between 1855-1875. But not only was Sweden relatively free from corruption as a result of these reforms, Sweden had become a highly effective state long before it became a democracy in 1921.

The Icelandic data is from the same survey we reported above while the Swedish data comes from an elite survey from 2012, where local top-politicians and high-level civil-servants in all of Sweden's municipalities were asked questions about their perceptions of corruption in Swedish local government. ${ }^{30}$

According to some of the literature reported above we expect political norms and administrative norms to differ. Administrators are expected to take a more principled stance towards potential corruption in accordance to the public interest while politicians are likely to be sensitive to how attentive participants in political life are to the task of serving voters. Hence, we subjected respondents to two different vignettes and asked for their evaluations. In the first vignette, we sought to capture political norms.

A member of the local council sits on the board of a company owned by the local authority and acts as deputy chair of a committee. He never reads minutes from meetings, almost never speaks and votes according to party lines. He receives payment for being on the board and only has to work half-time as a teacherbut still is comfortably off. How do you feel about this?

To test administrative norms, respondents were asked the following question:

(Supposing that:) In deciding on the procurement of goods for the elementary school your municipality decides to buy from a more expensive local supplier even if there are companies elsewhere offering goods of equal quality at a better price. How do you feel about this?

28 Michelle D’Arcy, Marina Nistotskaya and Robert Ellis, "State-Building, Democracy and Taxation: Why Ireland Will Never Be Sweden," University of Tokyo Journal of Law and Politics 12 (2015): 110-23.

29 Bo Rothstein, "Creating Political Legitimacy: Electoral Democracy versus Quality of Government," American Behavioral Scientist 53, no. 3 (2009): 311-3o.

Approximately 2,80o individuals received the survey, and the response rate was 69 percent. 
As indicated in the theoretical section above, we expect to find differences between the two groups, but we are looking for differences between the two countries as well. Political norms should be more strongly adhered to in both countries by politicians and administrative norms adhered to by administrators. Given the stronger prevalence of administrative norms in Sweden compared to the more politicized Icelandic context, we expect administrative norms to be stronger in Sweden and political norms to be stronger in Iceland.

\section{Results}

\section{Are there non-trivial variations in corruption tolerance?}

Let us turn to our first question: does tolerance of corruption vary? Table 2 shows the results in the ESS 2004 round, when respondents were asked for their evaluations of 'how wrong' they think it is for public officials asking a favor/bribe for service. Bribes are important, perhaps the best known and archetypical form of corruption, for which more data exists than for many other types of corruption.

Table 2. PUBLIC OFFICIAL ASKING FAVOR/BRIBE IN RETURN FOR SERVICE, HOW WRONG

\begin{tabular}{lll} 
& $\%$ & $\mathrm{~N}$ \\
\hline NOT WRONG AT ALL & 1.3 & 527 \\
\hline A BIT WRONG & 3.2 & 1288 \\
\hline WRONG & 27.9 & 11121 \\
\hline SERIOUSLY WRONG & 67.6 & 26967 \\
\hline TOTAL & 100.0 & 39903 \\
\hline
\end{tabular}

Table 2 shows two interesting patterns. On the one hand, the collective action approach to corruption seems vindicated in the sense that rejection of corruption is close to universal. Almost 95 percent of respondents think it is wrong or seriously wrong if public officials ask for favors/bribes in return for services; a mere 1 percent feel that it is not wrong at all. Thus, there is wide recognition of the harmful nature of corruption and we can safely assume that in an ideal world most people would like to get rid of it. However, there are different shades to the prevailing rejection of corruption. To some, bribes are "a bit wrong", to others merely "wrong" and to still others "seriously wrong." Given the option of choosing between "seriously wrong" and less decisive options, almost one out of three respondents choose milder options. Thus, Table 2 seems to establish for a relatively serious form of corruption that tolerance of corruption varies.

An additional result that questions "the universal shunning of corruption" hypothesis reveals itself in the special Eurobarometer research report from 2017 (European Commission 2017): more than one fifth of Europeans think that it is acceptable to do a favor in return for something they want from the public administration or a 
public service (22 percent) or to give a gift in return for something that they want $(21$ percent). Somewhat fewer (14 percent) think it is acceptable to give money to obtain something from the public administration or a public service. In an index consisting of these three questions, significant variations were observed between the EU-countries, ranging from 84 percent stating corruption as unacceptable (Portugal and Finland) to just a third thinking this is the case (Latvia and Hungary). The EU mean is 70 percent. The results from the ESS in 2004 as well as the Eurobarometer from 2017 warrant taking the next step and asking if tolerance of corruption is associated with actual levels of corruption.

\section{Association between corruption tolerance and corruption?}

A handful of previous studies have found variations in corruption tolerance or tolerance for other types of unethical behavior. ${ }^{31}$ Moreover, some have suggested that attitudes to corruption might vary with corruption levels. ${ }^{32}$ To illustrate this latter point, we stay with the example of bribes. In Graph 1, we display the relationship between Transparency International's Corruption Perception Index, and the data on tolerance of bribes from the European Social Survey (ESS) in 2004. We take the CPI to be a reasonable proxy for bribes even if it may be criticized on several accounts, including neglecting of other types of corruption. Graph 1 presents the results of a linear regression analysis of mean country scores involving tolerance of favoritism, on the one hand, and our proxy for corruption (i. e. the CPI) on the other.

In Graph 1, we observe relatively strong correlations between the tolerance of bribes and TI's evaluation in which experts' perceptions of the frequency of bribes play a strong role. Tolerance of bribes is relatively low in all the Nordic countries, including both Iceland and Sweden, and these countries are perceived among the least corrupt countries at the time of our measurement. Even if the data is somewhat dated, the relationship seems clear enough. The question is if something has changed since 2004.

To establish the reliability of our findings we ran a similar analysis on the relationship of acceptance of favoritism and perceived corruption in the member states of the EU in 2017. The data on corruption tolerance is from the Eurobarometer.

The relationship between corruption tolerance (in this case the acceptability of favoritism) is even stronger than in the previous graph, with $\mathrm{R}^{2}$ at .30. While we do not claim that tolerance of corruption is its main determinant, the results indicate that the 'universal dislike' hypothesis tends to be somewhat simplistic. Corruption may

$31 \quad$ Eric Chang and Nicholas Kerr, "An Insider-Outsider Theory of Popular Tolerance for Corrupt Politicians," Governance 30, no. 1 (2017): 67-84; Jan Magnus, Victore Polterovich, Dimitri Danilov and Alexei Sovvotev, “Tolerance of Cheating: An Analysis across Countries," The Journal of Economic Education 33, no. 2 (2002): 125-35.

32 Raymond Fisman and Edward Miguel, "Corruption, Norms and Legal Enforcement. Evidence from Diplomatic Parking Tickets," Journal of Political Economy 115, no. 6 (2007): 1020-48. 


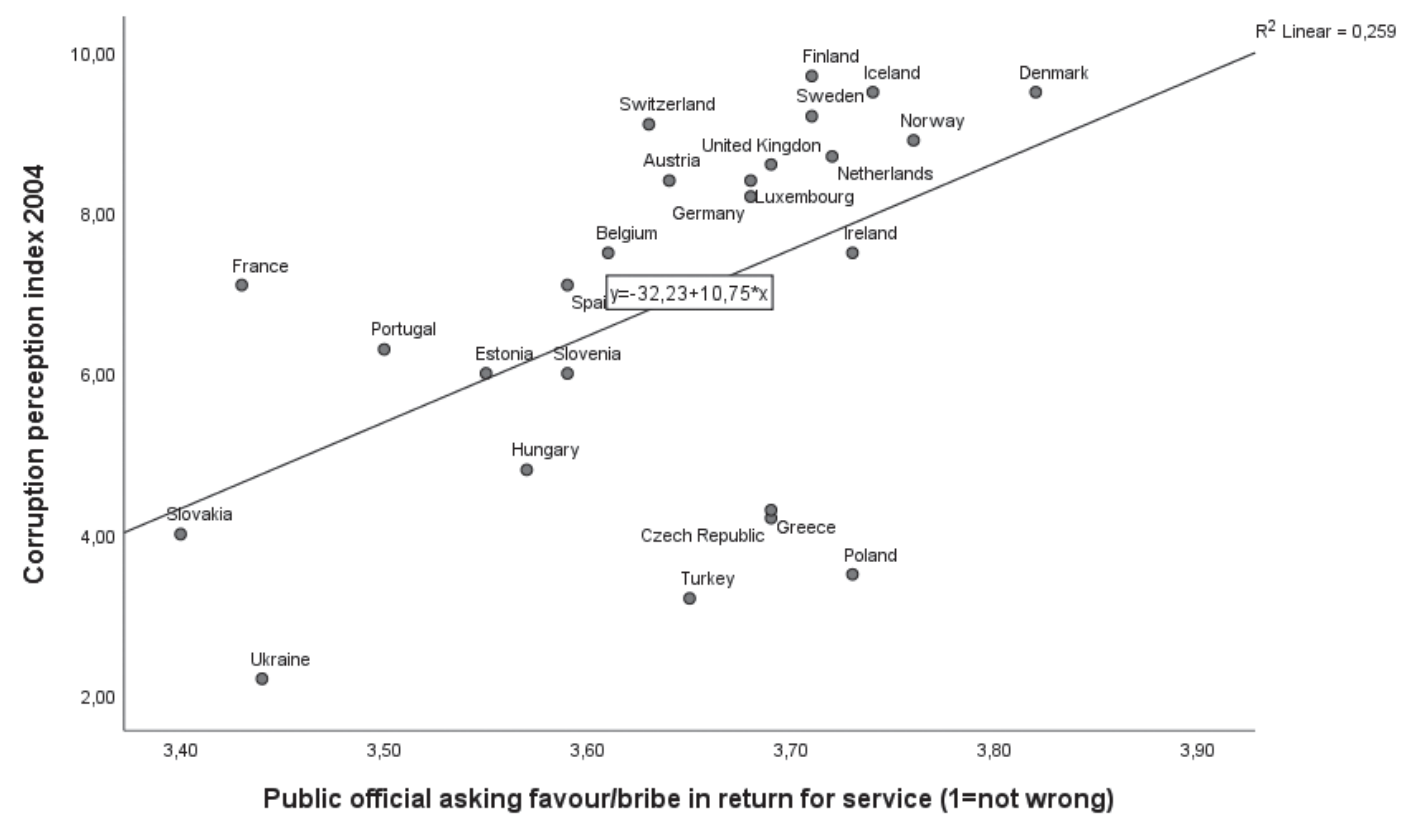

Graph 1.

TOLERANCE OF CORRUPTION AND PERCEIVED LEVELS OF CORRUPTION

Corruption perception index: o (no corruption) to 10 (high corruption)

Tolerance of corruption: Scale from 1 (not wrong) to 4 (seriously wrong)

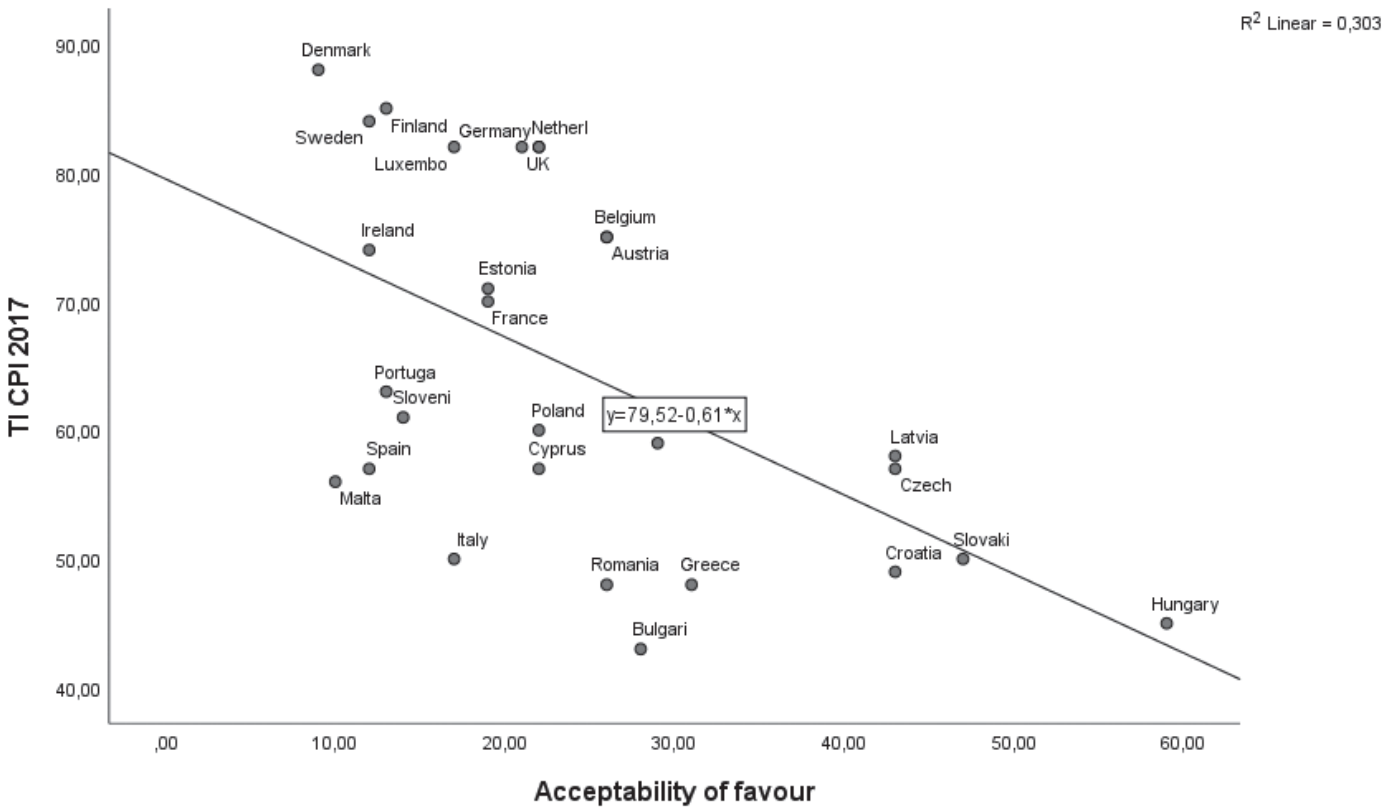

Graph 2.

TOLERANCE OF FAVORITISM AND PERCEIVED CORRUPTION 
be disliked. But variations in attitudes are, nonetheless, systematically related to the actual extent of corruption.

Our data, thus, supports H1. Having tentatively established a relationship of corruption tolerance to actual corruption, we now turn to an attempt to empirically elaborate on which mechanisms may be at work. In what follows, we start by looking at the 'closeness to power'-hypothesis (or a version of the 'power corrupts'-argument), and then study the relationship between political and administrative norms to corruption tolerance.

\section{Closeness to power: elite versus non-elite?}

For the Icelandic case, we have data which allows us to compare the attitudes of politicians, administrators and the public in Icelandic municipalities over a range of corruption issues (see Table 3 below). To simplify the presentation, we have constructed an index of corruption tolerance where answers on the six corruption items were projected on a scale from o (no tolerance of corruption) to 100 (full tolerance).

Table 3 .

TOLERANCE OF CORRUPTION IN ICELANDIC MUNICIPALITIES (INDEX 0-100)

\begin{tabular}{llll} 
& POLITICIANS & ADMINISTRATORS & PUBLIC \\
\hline BRIBES & 0.6 & 1.8 & 5.6 \\
\hline FRAUD & 7.4 & 6.8 & 6.6 \\
\hline EMBEZZLEMENT & 0.9 & 0.4 & 6.6 \\
\hline EXTORTION & 4.7 & 6.9 & 10.5 \\
\hline FAVORITISM & 7.6 & 6.3 & 11.5 \\
\hline PRIVATE INTERESTS & 20.7 & 11.9 & 18.6 \\
\hline INDEX (MEAN) & 7.1 & 5.4 & 10.9 \\
\hline
\end{tabular}

Note: for questionnaire items, see Table 1 above.

Table 3 shows rather low degrees of tolerance of corruption among all three groups in Iceland. However, the pattern of "corrupt elites" and the "pure people" can definitely be questioned. The public is indeed more tolerant of corruption than the two elite groups, while the elite group more directly accountable to the public, the politicians, is more tolerant of corruption than the administrators, though, obviously, the difference is neither large nor consistent. Least tolerant of corruption are the administrators, even if they have relatively direct access to power without bearing direct political accountability. Thus, $\mathrm{H}_{2}$ does not find support in our data.

\section{Administrative and political norms: Iceland and Sweden}

If the elite is less tolerant of corruption than the public, as our findings suggest, and the part of the elite that is less directly accountable to voters is also less tolerant of 
corruption, we are left with the interesting issue of what might shape elite norms regarding corruption. We suggested above that administrative norms might be different from those associated with political life, while historical and institutional factors might influence the relative weight of different norms between countries. Administrators are likely to be more sensitive to administrative norms than politicians while the reverse holds for politicians. Given Iceland's history of democratization before bureaucratization (and vice versa for Sweden), we moreover expect political norms to be more strongly adhered to in Iceland than in Sweden among both administrators and politicians. In the historically strong bureaucratic state of Sweden, by contrast, we expect administrative norms to prevail among both groups. The results are shown in Table 4.

Table 4. Political and Administrative Norms in Iceland and Sweden POLITICAL NORMS: ACCEPTABILITY OF COUNCIL MEMBERS NEGLECTING DUTIES

\begin{tabular}{llllll} 
EVALUATION & ICELAND & & SWEDEN & \\
\hline & Administrators & Politicians & Administrators & Politicians \\
\hline $\begin{array}{l}\text { Unacceptable } \\
\text { Questionable but }\end{array}$ & 64.9 & 72.4 & 29.9 & 40.7 \\
\hline $\begin{array}{l}\text { unacceptable } \\
\text { Questionable but }\end{array}$ & 2.7 & 24.8 & 17.6 & 18.2 \\
$\begin{array}{l}\text { acceptable } \\
\text { Acceptable }\end{array}$ & 1.4 & 1.9 & 36.1 & 30.7 \\
\hline \begin{tabular}{l} 
Total \\
\hline
\end{tabular} & 100 & 1.0 & & 16.4 & 12.8 \\
\hline
\end{tabular}

ADMINISTRATIVE NORMS: ACCEPTABILITY OF LOCAL PREFERENCE IN PUBLIC PROCUREMENT

\begin{tabular}{|c|c|c|c|c|}
\hline EVALUATION & ICELAND & & SWEDEN & \\
\hline & Administrators & Politicians & Administrators & Politicians \\
\hline Unacceptable & 37.8 & 19.2 & 56.1 & $45 \cdot 4$ \\
\hline $\begin{array}{l}\text { Questionable but } \\
\text { unacceptable }\end{array}$ & $27 \cdot 0$ & $33 \cdot 9$ & 24.8 & 24.6 \\
\hline $\begin{array}{l}\text { Questionable but } \\
\text { acceptable }\end{array}$ & $29 \cdot 7$ & $43 \cdot 1$ & 12.0 & 22.1 \\
\hline Acceptable & $5 \cdot 4$ & $3 \cdot 7$ & $7 \cdot 0$ & $7 \cdot 9$ \\
\hline Total & 100 & 100 & 100 & 100 \\
\hline
\end{tabular}

The findings in Table 4 are striking considering the theoretical expectations we outlined. We find marked differences in the normative standards of politicians and administrators in all cases, irrespective of country. Both in Sweden and Iceland, politicians are considerably more sensitive to breaches against 'political norms' and administrators to violations of "administrative norms." Furthermore, the differences between Iceland and Sweden are markedly in the expected direction, with the Icelandic 
respondents among both politicians and administrators being more sensitive to "political norms," while the Swedish respondents in both groups are more sensitive to "administrative norms." The findings basically accord with the theoretical expectations we formulated, based on the two countries' different pathways to state-capacity and representative democracy respectively. If you construct a functioning bureaucracy and a strong state-capacity before the introduction of representative democracy, administrative norms will be strong. If representative democracy precedes statecapacity, political norms will tend to dominate. This is in line with our $\mathrm{H}_{3} \mathrm{a}$ and $\mathrm{H}_{3} \mathrm{~b}$.

\section{Conclusions}

The aim here has been to tentatively explore tolerance of corruption, and more precisely, to delve deeper into the factors that seem to determine how individuals normatively evaluate this problem. To give context to the issue, as well as demonstrate the relevance of the research problem, we initially showed that non-trivial variations in corruption tolerance among individuals can be found, and that these seem to be associated with actual corruption levels even within a sample of relatively low-corruption European countries. We therefore proceeded to tentatively explore what may contribute to the understanding of varying levels of corruption tolerance among individuals by taking a closer look at data collected from two, in many ways similar countries, that historically have been seen as exceptionally spared from the plagues of corruption: Iceland and Sweden. The main takeaways from our analyses are the following:

- Corruption tends to be disliked by most people. There are variations, nonetheless, in the intensity of this attitude. In this sense, we can speak of slight, although interesting and non-negligible, variations in corruption tolerance.

- Variations in corruption tolerance are significantly related to actual levels of corruption at the country level, at least in the case of favors/bribes. This gives cause to explore the relationship between the two: what mechanisms are at work that may account for the relationship?

- Being close to power and with that proximity, access to the "supply-side" of corruption, does not imply greater tolerance of corruption. Rather, at least from data gathered in the Icelandic setting, we can comparatively safely reject the hypothesis about the "pureness of the people" and the "corrupt elite", and by implication, question the "power corrupts"-hypothesis. In fact, if anything, the pattern indicates that the group most tolerant to diverse types of corruption, is the general public.

- We observed interesting differences between Iceland and Sweden regarding "professional ethics". What we label as "political norms" are stronger in Iceland, while "administrative norms" are stronger in Sweden. We make the case that these striking differences between two rather similar settings can be attributed to both nation's differing trajectories in the timing of when their state-capacity and representative democracy, respectively, were consolidated. An implication of this finding is that, at least as a tentative working hypothesis, the strength of 
administrative norms in Sweden have provided an important defense against patronage and clientelism, a defense that historically has not been as strong in Iceland.

- Lastly, in several of our analyses, as to different forms of corruption, civil servants tend to be slightly less tolerant than, e.g., politicians and citizens. Working hypotheses to explain those findings could be that there is a) a self-selection to civil service, b) civil servants' specific education and preparation for civil service infuses them with greater ethical standards, and c) learning and socialization in the workplace may reinforce these values.

The last result, that civil servants tend to have lower tolerance for administrative corruption than both the public as well as the politicians, has implications that warrant elaboration. Thus, it is worth remembering that in the 1970s and 198os, strong claims from neoclassical economics, public choice-theorists and other were made about bureaucracy being rigid, hopelessly ineffective and a costly dinosaur involved in a death struggle. As Johan P. Olsen has demonstrated, several scholars, think-tanks and interest organizations have maintained that bureaucracy was "obsolescent, undesirable, and non-viable form of administration and that there is an inevitable and irreversible paradigmatic shift towards market or network organization." 33

Proclaiming the death of bureaucracy may have been premature, however. The alternatives to the classical bureaucratic model have not proved to have been too attractive. A first observation is that a body of literature has demonstrated that reforms associated with New Public Management - e. g., privatization and outsourcing of public services - may have been detrimental to core democratic values such as transparency, accountability and public ethics. ${ }^{34} \mathrm{~A}$ second observation is that a growing number of empirical studies have demonstrated that the more autonomous bureaucracies are from politics, the better political systems tend to work in a number of dimensions, including, for example, better growth, lower corruption levels and greater well-being among citizens. ${ }^{35}$ In other words, there seems to be something to or in bureaucracies that promotes factors that are attractive and desirable for the society as a whole.

What could this something be? Some of the literature on corruption attempts to model it as either a principal-agent problem or a collective-action problem. The weakness of the principal-agent model, at least according to our account, is that although

33 Johan P. Olsen, "Maybe It Is Time to Rediscover Bureaucracy," Journal of Public Administration Research and Theory 16 (2005), 1-16.

34 See for instance, Richard Box, et al, "New Public Management and Substantive Democracy," Public Administration Review 61 (2001): 6o8-19; H. George Fredricksson, "Ethics and the New Managerialism," Public Administration \& Management 4, no. 2, (1999): 299-324; Annie Hondeghem, Ethics and Accountability In a Context of Governance and New Public Management (Amsterdam: IOS Press, 1998). government: What you get," Annual Review of Political Science 12 (2009): 135-61. 
people are unlikely to engage in corruption without benefiting from it, closeness to power seems not to be a sufficient condition for increasing tolerance of corruption. Indeed, the public may be more tolerant of corruption than civil servants. Similarly, if the collective action model is taken to mean that values and norms are irrelevant to actual corruption because of a universal rejection of it, this is not supported by our data. Tolerance of corruption varies, and it is related to actual corruption levels. Absent from both accounts, principal-agent and collective action, is the notion that norms may matter.

We do not make a strong claim here that norms should been seen as the main determinants of behavior. The pattern is most likely more complicated than that. Norms are shaped by contexts as rules for appropriate behavior for different roles and are often maintained in a mixture of formal structure and informal networks. They are likely to adapt to some extent to established practices in different spheres of society. The norms appropriate from one sphere to another, however, are likely to differ. Norms that counterbalance the incentives of politicians to develop particularistic exchange relationships may often be found in well-organized bureaucracies.

Thus, one interpretation that at least tentatively receives some support in the data we present is that there are characteristics at the individual civil servant-level that could make the connection between "autonomous bureaucracies" and certain desirable societal outcomes intelligible. We saw it in Table 2, where the Icelandic data revealed that civil servants are considerably less tolerant to different practices related to the concept of corruption than politicians and the public. We saw it above where civil servants in both Sweden and Iceland, are considerably less prone to accept deviations from the norm of impartiality in public procurement processes. In addition, although admittedly not as clear-cut, data on Sweden from WWS (2014), has shown that public sector employees more often than private sector employees to think that it is never justifiable to accept a bribe. ${ }^{36}$

As discussed in the introductory section, in the public administration literature we find scholars who normatively argue that civil servants ought to have higher ethical standards than the general public and politicians that there ought to be a distinct "bureaucratic ethos" or a "public administration ethics." Related to this, some scholars seem to explicitly argue that there is a gap between the normative prescriptions on which ethics civil servants ought to have, and the ethics they de facto do have. Hence for instance, Lennart Levi and Bo Rothstein proposed that all institutions of higher education should adapt their training in order to instill ethical thinking and critical thinking as well as skills to deal with ethical dilemmas. This is a widespread opinion also within the top echelons of government in individual countries where various kinds of ethical codes or codes of conduct have been introduced in order to strengthen

36 Ca. 71 percent of public sector employees state it is never acceptable to accept a bribe, while ca. 66 percent of the private sector employees state the same thing. As an interesting side-note, in the same data, 66 percent of public sector employees state it is never justifiable to cheat on taxes, corresponding figure is ca. 59 percent of private sector employees. 
public sector ethics. One must reasonably assume that this is done because there is a widespread perception for the need of this; that is, that the ethical compasses of civil servants are not well-calibrated enough. Our results indicate that the problem may perhaps be smaller than is thought, at least within the countries surveyed in this paper. In Sweden and Iceland, we observe slightly higher ethical standards among civil servants than among politicians and ordinary citizens; indicating precisely what Robert P. Goss called "distinct public administration ethics". Following Gary Miller, ${ }^{37}$ this is highly desirable. It indicates that the political system has been able to hire its managers with preferences distinct from citizens as well as politicians, a condition advocated by Miller. Giving bureaucracies autonomy and discretion increases the probability of the system having a credible commitment to neutrality, impersonality, efficiency, and, ultimately, anti-corruption.

From an anti-corruption perspective, this result signal so something promising. The criteria for good performance in a bureaucracy are very different from those prevailing in a politicized environment, where we would expect civil-servants to focus on professional competence and impartiality, but where political elites may be tempted to find ways to extract surplus rents and give paybacks to lobbyists or their supporters, such as voters, constituencies and donors/financiers. For anti-corruption purposes, and as argued in the so called "Quality of Government" perspective, ${ }^{38}$ it is crucial that politicians should be kept at an arm's length from civil servants so that bureaucracies are kept reasonably autonomous from politicians. In this sense, the bureaucracy can become a necessary counterbalance to the power of politicians and, as suggested above, could be a necessary component of a well-functioning democracy because the democracy is at least relatively spared from corruption.

\section{Bibliography}

Aberbach, Joel, Robert Putnam, and Bert Rockman. Bureaucrats and Politicians in Western Democracies. Cambridge: Harvard University Press, 1981.

Andersson, Staffan and Gissur Ó. Erlingsson. "New Public Management and Danger Zones for Corruption," In The Social Construction of Corruption in Europe, edited by Dirk Tänzler, et al, 33-58. Farnham, Burlington: Ashgate Press, 2012.

Bardhan, Pranab. "Corruption and Development: A Review of the Issues." Journal of Economic Literature 35, no. 3 (1997): 1320-46.

Becker, Gary S. “Crime and Punishment: An Economic Approach.” The Journal of Political Economy 76, no. 2 (1968): 169-217.

37 Gary Miller, "Above Politics: Credible Commitment and Efficiency in the Design of Public Agencies," Journal of Public Administration Research and Theory 10, no. 2 (2000): 289-327.

38 For instance, Carl Dahlström, Victor Lapuente, Organizing Leviathan (Cambridge: Cambridge University Press, 2017). 
Becker, Katharina, Christian Hause, and Franz Kronthaler. "Fostering Management Education To Deter Corruption: What Do Students Know About Corruption and Its Legal Consequences?" Crime, Law and Social Change 6o, no. 2 (2013): 227-40.

Bierstaker, James Loyd. "Differences In Attitudes About Fraud And Corruption Across Culture: Theory, Examples And Recommendations." Cross Cultural Management: An International Journal 16, no. 3 (2009): 224-50.

Box, Richard et al. "New Public Management and Substantive Democracy." Public Administration Review 61 (2001): 6o8-19.

Chang, Eric and Nicholas Kerr. "An Insider-Outsider Theory of Popular Tolerance for Corrupt Politicians." Governance 30, no. 1 (2017): 67-84.

Collier, Michael. "Explaining Corruption: An Institutional Choice Approach." Crime, Law and Social Change 38, no. 1 (2002): 1-32.

Dahlström, Carl, and Victor Lapuente. Organizing Leviathan. Cambridge: Cambridge University Press, 2017.

D'Arcy, Michelle, Marina Nistotskaya, and Robert Ellis. "State-Building, Democracy and Taxation: Why Ireland Will Never Be Sweden." University of Tokyo Journal of Law and Politics 12 (2015): 110-123.

DeCelles, K. A., D. S. DeRue, J. D. Margolis, and T. L. Ceranic. "Does Power Corrupt or Enable? When and Why Power Facilitates Self-Interested Behaviour." Journal of Applied Psychology 97, no. 3, (2012): 681-89.

Erlingsson, Gissur Ó. and Gunnar Helgi Kristinsson. "Measuring Corruption: Whose Perceptions Should We Rely On?" Icelandic Review of Politics \& Administration 12, no. 2, (2016): 215-35.

Erlingsson, Gissur Ó., Jonas Linde, and Richard Öhrvall. "Distrust in Utopia? Public Perceptions of Corruption and Political Support in Iceland Before and after the Financial Crisis in 2008." Government and Opposition 51, no. 4, (2016): 553-79.

European Commission. "Special Eurobarometer 470." Brussels: European Commission, 2017.

Fisman, Raymond and Edward Miguel. "Corruption, Norms and Legal Enforcement. Evidence from Diplomatic Parking Tickets." Journal of Political Economy 115, no. 6 (2007): 1020-48.

Fredricksson, H. George. "Ethics and the New Managerialism." Public Administration \& Management 4, no. 2, (1999): 299-324.

Gilman, Stuart C. Ethics Codes and Codes of Conduct as Tools for Promoting an Ethical and Professional Public Service: Comparative Successes and Lessons. Washington D. C.: World Bank, 2005.

Goss, Robert P. “A Distinct Public Administration Ethics." Journal of Public Administration Research and Theory 6, no. 4, (1996): 573-97.

Granovetter, Mark. "Threshold Models of Collective Behaviour." The American Journal of Sociology 83, no. 6, (1978): 1420-43.

Holmberg, Sören, Bo Rothstein and Naghmeh Nasiritousi."Quality of Government: What You Get." Annual Review of Political Science 12 (2009): 135-61. 
Hondeghem, Annie. Ethics and Accountability in a Context of Governance and New Public Management. Amsterdam: IOS Press, 1998.

Huntington, Samuel. Political Order in Changing Societies. New Haven: Yale University Press, 1968.

Kristinsson, Gunnar H. Embæettismenn og Stjórnmálamenn. Reykjavík: Heimskringla, 1993.

Kristinsson, Gunnar H. "Party Patronage in Iceland: Rewards and Control Appointments" In Party Patronage and Party Government in European Democracies, edited by Peter Kopecky. Oxford: Oxford University Press, 2012.

Kuran, Timur. Private Truths, Public Lies. The Social Consequences of Preference Falsification. Harvard: Harvard University Press, 1997.

Levi, Lennart and Bo Rothstein. "Educating Ethical Leaders and Critical Thinkers." University World News, January 12, 2018. http://www.universityworldnews.com/ article.php?story=2018010915074826o.

Magnus, Jan, Victore Polterovich, Dimitri Danilov and Alexei Sovvotev. "Tolerance of Cheating: An Analysis across Countries." The Journal of Economic Education 33, no. 2 (2002): 125-35.

Manzetti, Luigi, and Carole Wilson. "Why do Corrupt Governments Maintain Public Support." Comparative Political Studies. 40, no. 8 (2007): 949-70.

Meyer-Sahling, Jan-Hinrik, Kim Sass Mikkelsen, and Christian Schuster. "The Causal Effect of Public Service Motivation on Ethical Behavior in the Public Sector: Evidence from a Large-Scale Survey Experiment." Journal of Public Administration Research and Theory 29, no. 3 (2019): 445-59.

Miller, Gary. "Above Politics: Credible Commitment and Efficiency in the Design of Public Agencies." Journal of Public Administration Research and Theory 10, no. 2 (2000): $289-327$.

Mudde, Cas. "The Populist Zeitgeist." Government and Opposition 39, no. 3 (2004): $541-63$.

Ocantos, Ezeuiel, Chad de Jontge, and David Nickerson. "The Conditionality of VoteBuying Norms: Experimental Evidence from Latin America." American Journal of Political Science 58, no. 1, (2014): 187-211.

Persson, Anna, Bo Rothstein and Jan Teorell. "Why Anticorruption Reforms Fail: Systemic Corruption as a Collective Action Problem." Governance 26, no. 3 (2013): 449-71.

Rothstein, Bo. Social Traps and the Problem of Trust. Cambridge: Cambridge University Press, 2005.

Rothstein, Bo. "Creating Political Legitimacy: Electoral Democracy versus Quality of Government." American Behavioral Scientist 53, no. 3 (2009): 311-30.

Rothstein, Bo. "Anti-Corruption: the Indirect 'Big Bang' Approach." Review of International Political Economy 18, no. 2, (2011): 228-50.

Rothstein, Bo and Ayisha Varraich. Making Sense of Corruption. Cambridge: Cambridge University Press, 2017. 
Schelling, Thomas. "Dynamic Models of Segregation." Journal of Mathematical Sociology 1 (1971): 143-86.

Shefter, Martin. Political Parties and the State. (Princeton: Princeton University Press, 1994).

Silberman, Bernard. Cages of Reason. The Rise of the Rational State in France, Japan, the United States, and Great Britain. Chicago: The University of Chicago Press, 1993.

Wright, Bradley, Shahidul Hassan, and Jongsoo Park. "Does a Public Service Ethic Encourage Ethical Behaviour? Public Service Motivation, Ethical Leadership and the Willingness to Report Ethical Problems." Public Administration 94, no. 3 (2016): $647-63$.

Ziller, Conrad and Thomas Schübel. “The Pure People' versus 'the Corrupt Elite'? Political Corruption, Political Trust and the Success of Radical Right Parties in Europe." Journal of Elections, Public Opinion and Parties 25, no. 3 (2015):368-86.

(2)

Gissur Ó Erlingsson is an associate professor in political science, Linköping University, Sweden. His main research interest is corruption and other forms of illicit or unethical practices in the public sector. Erlingsson has published himself on these issues in journals such as Governance, International Journal of Public Administration, Government and Opposition, Public Integrity and Local Government Studies; as well as the monograph A Clean House: Studies of Corruption in Sweden (Nordic Academic Press).

Gunnar Helgi Kristinsson is a professor in political science, University of Iceland, Iceland. Kristinsson is an expert on political trust, legitimacy and issues pertaining to irregularities in public decision making, such as clientelism, patronage and other practices related to corruption. He is published on these topics in journals such as Acta Politica, West European Politics and Icelandic Review of Politics and Administration, as well as edited volumes such as Party Patronage and Party Government in European Democracies (Oxford University Press) and Clientelism, Interests, and Democratic Representation (Cambridge University Press). 